\title{
Determining the Performance of Procurement Methods against Selection Criteria using Outranking - Satisfying Methodology
}

\author{
OJO Stephen Okunlola ${ }^{1}$ and IKPO Imeh Johnson ${ }^{2}$ \\ ${ }^{1}$ Senior Lecturer, Department of Building, Obafemi Awolowo University, Ile-Ife, Nigeria. E-mail: sojo_uk@yahoo.com \\ (Corresponding author) \\ ${ }^{2}$ Professor, Department of Building, Obafemi Awolowo University, Ile-Ife, Nigeria. E-mail: iikpo@oauife.edu.ng
}

Project Management

Received August 17, 2012; received revisions October 2, 2012; October 25, 2012; November 28, 2012; accepted December 1, 2012 Available online January 25, 2013

\begin{abstract}
The need to develop a decision support system to determine the most appropriate procurement route for a building project led to the development of various theoretical models. One of the foremost techniques was the multiattribute utility approach (MAUA). In this technique, the arithmetic mean (averaging) method was used to fix the utility factors relating the procurement routes to each criterion. In this paper, the averaging method was subjected to further analysis using the outranking-satisfying technique to determine the correctness of the results derived from the averaging method used to fix the utility factors in the use of MAUA. The results showed that there is a significant difference between the rank-order of procurement methods against selection criteria by averaging and outranking-satisfying techniques. The use of outranking-satisfying analysis revealed that, the use of arithmetic mean to determine the utility factors can lead to inappropriate association of procurement routes with differing utility coefficients.
\end{abstract}

Keywords: procurement method, selection criteria, utility factors, multi-attribute utility, outranking satisfying analysis.

\section{Introduction}

The use of appropriate procurement method to implement construction projects was brought to the fore after the release of Latham's (1964) and Emerson's, (1994) reports. Clients were advised to use and demand for appropriate procurement method on their projects to mitigate the effects of time and cost overruns of construction projects on the economy and the growth of the construction industry. This demand led to an increase of research efforts to determine the most appropriate procurement method for a construction project. Several theoretical models have been proposed and developed. These include the discriminant analysis approach (Skitmore and Marsden, 1988), multivariate analysis (Chan et al., 2001), decision support systems (Kumaraswamy and Dissanayaka, 2001), the multi-attribute utility approach (MAUA) (Bennett and Grice, 1990, Love et al., 1998, Chan, 1995), and the analytical hierarchical process (Cheung et al., 2001). Ojo and Aina (2010) also developed a weighted model to determine the most appropriate procurement option using the averaging method to fix the performance of the procurement options on the selection criteria for building types and cost categories. Ren et al. (2012) acknowledged that the selection of an appropriate strategy has long been identified as a major contributor to project success but suggested that the route which is most appropriate depends on the goals, requirements and success available. $\mathrm{Ng}$ et al. (2002), believes none of these models has been adopted widely in practice because of lack of a universally applicable set of criteria for determining the appropriateness of a procurement system (Ireland, 1985). But the multi-attribute utility approach (MAUA) has been regarded by Love et al. (1998) as the "foremost technique appropriate for examining the criteria of clients and the preferences of experts' weight for each method in the most objective way."

The multi-attribute utility as applied to selection of procurement routes in construction management involves four steps (Chang and Ive, 2002):

a) identification of priority variables (i.e. criteria);

b) fixing the utility factors by experts relating achievement of priority variables as outcomes to procurement routes;

c) determination of relative importance attached to each criterion;

d) summing up the weighted priority variable of each procurement route and choosing the one with highest score.

In fixing the utility factors, Love et al. (1998) mentioned the problem of obtaining it by objective means and also the difficulty in reaching a consensus on the 
factor weight. To overcome these problems, researchers (Love et al., 1998; Chan, 1995; Chan et al., 2001; Cheung et al., 2001) have asked experts to subjectively assess the performance of each procurement method against each priority factor. Most of these researchers have asked the "experts" to rate on a scale of 0 to 10 (Kumaraswamy and Dissanayaka, 1998; Ambrose and Tucker, 2000) and 10100 (Bennett and Grice, 1990; Love et al., 1998; Chan, 1995; Chan et al., 2001; Cheung et al., 2001).

The earlier works in the procurement theory have used the traditional averaging method to fix the utility factors relating the procurement routes to each selection criterion. This paper however, postulates that further and rigorous analysis of the procurement methods' performance against selection criteria can be done using the outranking method of analysis to determine the "best-in-rank". It is similar to the analytical hierarchy process (AHP) technique used for analyzing complex decisions. According to Bilge and Sharmin (2012), it allows comparisons to be based on concreted data or human judgment and then evaluation converted into numerical values with weights. It is therefore the aim of this paper to seek to augment a theory of practice for benchmarking the performance of the procurement methods against selection criteria. This was done by comparing the rank-order derived from the utility factors using the averaging method with those derived from the outranking-satisfying analysis. The objective was to highlight the weakness or inappropriateness of the averaging method. The hypothesis of the research was that "there is no difference between the rank-order derived from the averaging and outranking-satisfying analysis".

\section{Performance Analysis}

The measure of performance (i.e. utility factors) of each procurement method has been an important issue in the search for the appropriate procurement method for a particular project. The utility factor is a relative measurement of suitability of a particular procurement method against a criterion (Fellows and Langford, 1980). Simply, the utility factors link client priority variable to the expected performance of each procurement method in terms of these variables. The procurement methods considered were design-bid-build (lump sum contract), direct labour system which are categorized by Dada (2012) as traditional procurement methods. Others were designbuild which according to Ogunsanmi et al. (2011) is attracted to clients because of its speed of project completion, cost reductions, simplified contracting and creation of single point responsibility; management contracting and the Build-Own-Operate-Transfer (BOOT) system which is the major variant of the emerging procurement methods. According to Chan et al. (2001), the utility factors provide a more objective analysis to alleviate the inconsistency and subjectivity in the decision making process due to emotional or environmental condition. There is need to make comparisons between the performance associated with the procurement methods but as acknowledged by Muriro and Wood (2010), there is the challenge of "how to compare procurement systems on a like-for-like basis". In determining the performance of procurement options against selection variables, the traditional arithmetic mean has been the most common method used. This method has been used for its simplicity and not for it rigour. It is represented by Eq. (1) (Jiukun et al., 2007):

$$
\text { Mean performance }\left(\mu_{\mathrm{P}}\right)=\frac{\sum_{i=1}^{N} P i}{N}
$$

Where $\left(\mu_{\mathrm{P}}\right)$ is the arithmetic mean performance on a criterion $\mathrm{i}=1,2,3, \ldots, \mathrm{N}$

and $\mathrm{N}$ is the number of respondents.

\subsection{Outranking-Satisfying Methodology}

Multi-criteria benchmarking analysis of organization learning capability according to Laise (2004) poses many problems because dominance relation is usually not verified and hence there is not a "best-in-rank" organization. In traditional benchmarking analysis of learning capability of organizations, this problem of the absence of a dominance relation is usually tackled by the construction of a synthetic indicator obtained by averaging the scores assigned to an organization on the different criteria (Goh and Richards, 1997; Drew, 1997; Sharif, 2002). Thus the "best-in-rank" is the organization with maximum averaged value, computed by averaging the scores assigned to all the criteria.

However, this averaging methodology has been acknowledged (Laise, 2004) as the main disadvantage of the traditional approach particularly when observations have high dispersion. But the application of outranking approach according to Laise (2004) enables the benchmarking of organization learning capability without the necessity of an aggregate indicator obtained by averaging all scores assigned to the organizations on the basis of the different criteria. The method involves successive pair wise comparisons of two alternatives to determine outranking relative with respect to the criteria.

\section{Research Methodology}

The research work was carried out through structured questionnaire survey administered to three classes of construction practitioners namely: clients, consultants and contractors. The client group was divided into two subgroups of public and private clients. The consultants were the Architects, Engineers, Quantity Surveyors and Builders, while the contractors were the large and medium sized companies listed in the register of the Federation of Construction Industry (FOCI). Two different questionnaires were designed for this research, one was for clients and consultants and the other for contractors. The clients and consultants questionnaire was divided into two parts. Part A deals with background information of respondents, particularly their experience level. In part B section 1 , issues relating to the respondents familiarity with the procurement options and selection criteria were asked. In section 2, respondents were asked to prioritise the selection criteria according to type of building and cost categories on a scale of 1-5. In section 3, the respondents were asked to rate the suitability of the commonly used procurement options in Nigeria in achieving a selection criterion using a scale of 1 to 10 . A rating of 1 means low suitability and 10 means high suitability in achieving a selection criterion. This was done for project cost categories of N10million (Naira) - N100million (Naira), N101 million (Naira) - N500 million (Naira) and above N500 million (Naira) costs. The selection criteria considered were speed, cost certainty, time certainty, price competition, quality, risk avoidance (in the event of time 
slippage) and risk avoidance (in the event of cost slippage). The questionnaire designed for contractors was divided into two parts. Part A asked the respondents to supply necessary information about their company. In part B, section 1 the questionnaire sought the familiarity of the respondents with the procurement options and also the experience based perceptions of the contractors on the performance of the procurement options on a selection criterion using a scale of 1-10. A scale of 1 (low suitability) to 10 (high suitability) was used to rate the performance of the procurement options to avoid any possible imbalances due to the occurrence of zeros (Fellows and Langford, 1980).

Senior managers and administrators in both the public and private organizations were targeted to respond to the questionnaires. This was done because they are directly involved in the choice of procurement methods using their experiences of the performance of the procurement methods against selection criteria. Similarly, experienced consultants who have been involved in past projects using some of these procurement methods were targeted for this group. As for contracting organizations, senior managers on site who are directly involved in using these procurement methods were targeted.

The questionnaires were used as interview schedule to capture answers to questions that were qualitative in nature. Thirty of the respondents who are senior managers and were willing were interviewed. The results of the research were also discussed with them.

Out of the 50 questionnaires administered to the clients using purposive sampling method, 39 (26 public and 13 private) questionnaires were correctly filled and received i.e. $78 \%$ response rate. A purposive sampling method was used to select the 132 consultants. Out of the 132 questionnaires distributed, 50 were received and after a thorough check, 27 were appropriate for analysis i.e. $20 \%$ response rate. The population of the contractors sampled in this study is 77 . The Mendenhall et al. (1971) formula for calculating sample size was used as in Eq. (2)

$$
n=\frac{N p q}{(N-1) \frac{B^{2}}{4}+P q}
$$

Where: $\mathrm{n}=$ sample size

$\mathrm{N}=$ population size

$\mathrm{e}=\mathrm{B}$, the confidence level of error of estimation $=0.05$

$\mathrm{p}=$ the population proportion with required characteristics (assumed to be 0.5)

$\mathrm{q}=$ the population proportion without the required characteristics $(q=1-p)$

Substituting values into Eq. (2)

$$
n=\frac{77(0.5)(0.5)}{(77-1) \frac{\left(0.05^{2}\right)}{4}+(0.5)(0.5)}=65 \text { contractors }
$$

Based on the Mendenhall et al. (1971) formula, the sample size for the contractors was 65 hence 65 questionnaires were distributed using random sampling technique. Thirty-six questionnaires were returned but 27 (i.e. $42 \%$ response rate) were appropriate for analysis.

For the purpose of this research work, the results of mean performance of procurement options on selection criteria by public clients Table 2 of Ojo (2009) is published as Table 1 for all cost categories for illustration.

\section{The Outranking - Satisfying Analysis}

To highlight the disadvantage of the traditional averaging approach and advantage of the outranking method, an outranking analysis was performed on the values/weighting derived from the averaging method as in Table 1.

The multi criteria matrix, matrix of concordance and concordance threshold test constructed for project cost of N10 million (Naira) - N100 million (Naira) by public clients are presented in Tables 2, 3 and 4 respectively. Those for N101 million (Naira) - N500 million (Naira) and above N500 million (Naira) cost categories are presented in Tables, 5, 6, 7 and 8, 9 and 10 respectively.

The mean performance of the procurement options as in Table 1 on each criterion was used to construct the multi-criteria matrix in Tables 2, 5 and 8 . The average values in the tables' (last column) for any procurement alternative $\mathrm{N}$, are obtained as follows:

Average (Alternative $\mathrm{N})=\left(\mathrm{C}_{1}\right.$ (Alternative $\mathrm{N}+\mathrm{C}_{2}$ (Alternative $\mathrm{N})+\ldots \mathrm{C}_{7}($ Alternative $\mathrm{N}) / 7$

Using the average values, one can order the set of the procurement alternative as in Fig. 1.

By Table 2, the lump contract had the highest score, hence the "best-in-rank" and so ordered first in Fig. 1. The BOOT system had the least average value hence ordered last. Now to illustrate the application of the outrankingsatisfying methodology, let us consider Table 2 again comparing the performance of lump sum contract and management contracting on each criterion. By Table 2, lump sum contract is better than management contracting on four criteria out of seven, while management contracting is better than lump sum contract on three criteria out of seven.

The generic element is $\mathrm{J}^{\mathrm{c}}(\mathrm{PMi}, \mathrm{PMj})=\mathrm{J} \epsilon / \mathrm{Cj}(\mathrm{PMi}) \geq$ $\mathrm{Cj}(\mathrm{PMj})$

$$
\text { Where } \mathrm{J}=(1,2,3,4,5,6,7)
$$

Taking into consideration the weights assigned to the various criteria, a concordance index was calculated for each pair of procurement method alternative (PMi, PMj) as: $\mathrm{CI}(\mathrm{PMi}, \mathrm{PMj})=\sum K j J \varepsilon J^{c}$

Where $\mathrm{Kj}$ is the weight assigned to the $\mathrm{J}^{\text {th }}$ criterion. Now for example, for the pair of lump sum contract and management contracting, assuming equal importance or weight is attached to all criteria, then we have:

CI (lump sum contract, management contracting) $=\mathrm{K}_{1}$ $+\mathrm{K}_{2}+\mathrm{K}_{4}+\mathrm{K}_{6}=1 /{ }_{7}+1 / 7+1 / 7+1 / 7=0.57$ (57 percent) $(6)$ 
Table 1. Mean performance of procurement methods on selection criteria by public clients

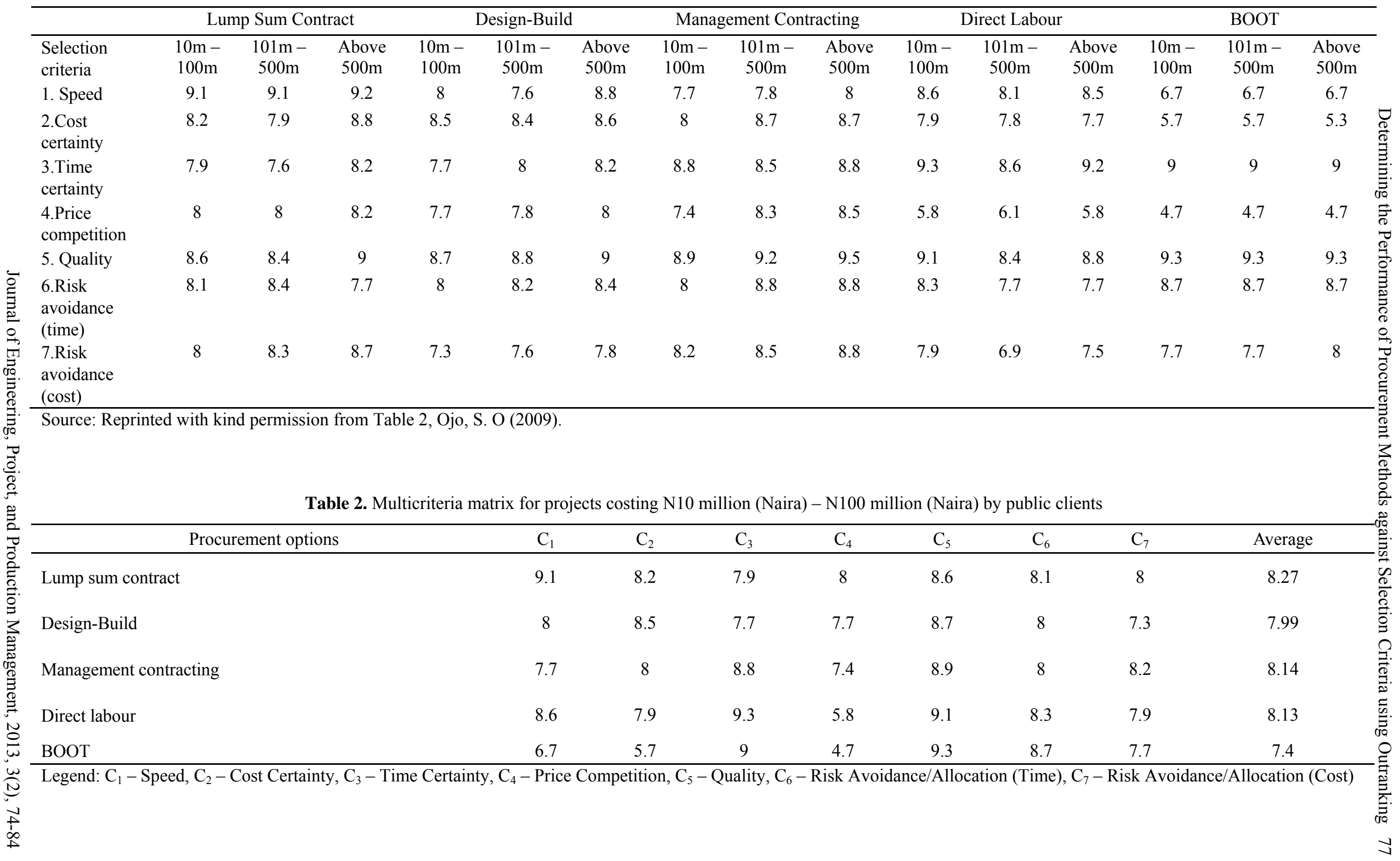


Table 3. Matrix concordance subsystem $\left(\mathrm{J}^{\mathrm{c}}\right)$ by public clients

\begin{tabular}{|c|c|c|c|c|c|}
\hline Procurement options & $\begin{array}{l}\text { Lump sum } \\
\text { contract }\end{array}$ & Design- Build & $\begin{array}{l}\text { Management } \\
\text { contracting }\end{array}$ & Direct labour & BOOT \\
\hline Lump sum contract & & $\begin{array}{c}\left\{\mathrm{C}_{1}, \mathrm{C}_{3}, \mathrm{C}_{4}, \mathrm{C}_{6}\right. \\
\left.\mathrm{C}_{7}\right\} \\
(71 \%)\end{array}$ & $\begin{array}{c}\left\{\mathrm{C}_{1}, \mathrm{C}_{2}, \mathrm{C}_{4}, \mathrm{C}_{6}\right\} \\
(57 \%)\end{array}$ & $\begin{array}{c}\left\{\mathrm{C}_{1}, \mathrm{C}_{2}, \mathrm{C}_{4}, \mathrm{C}_{7}\right\} \\
(57 \%)\end{array}$ & $\begin{array}{c}\left\{\mathrm{C}_{1}, \mathrm{C}_{2}, \mathrm{C}_{4}, \mathrm{C}_{7}\right\} \\
(57 \%)\end{array}$ \\
\hline Design-Build & $\begin{array}{c}\left\{\mathrm{C}_{2}, \mathrm{C}_{5}\right\} \\
(28.60 \%)\end{array}$ & & $\begin{array}{c}\left\{\mathrm{C}_{1}, \mathrm{C}_{2}, \mathrm{C}_{4}\right\} \\
(42.90 \%)\end{array}$ & $\begin{array}{c}\left\{\mathrm{C}_{2}, \mathrm{C}_{4}\right\} \\
(28.60 \%)\end{array}$ & $\begin{array}{c}\left\{\mathrm{C}_{1}, \mathrm{C}_{2}, \mathrm{C}_{4}\right\} \\
(42.90 \%)\end{array}$ \\
\hline $\begin{array}{l}\text { Management } \\
\text { contracting }\end{array}$ & $\begin{array}{c}\left\{\mathrm{C}_{2}, \mathrm{C}_{5}, \mathrm{C}_{7}\right\} \\
(42.90 \%)\end{array}$ & $\begin{array}{c}\left\{\mathrm{C}_{3}, \mathrm{C}_{5}, \mathrm{C}_{7}\right\} \\
(42.90 \%)\end{array}$ & & $\begin{array}{c}\left\{\mathrm{C}_{2}, \mathrm{C}_{4}, \mathrm{C}_{7}\right\} \\
(42.90 \%)\end{array}$ & $\begin{array}{c}\left\{\mathrm{C}_{1}, \mathrm{C}_{2}, \mathrm{C}_{4}, \mathrm{C}_{7}\right\} \\
(57 \%)\end{array}$ \\
\hline Direct labour & $\begin{array}{c}\left\{\mathrm{C}_{3}, \mathrm{C}_{5}, \mathrm{C}_{6}\right\} \\
(42.90 \%)\end{array}$ & $\begin{array}{c}\left\{\mathrm{C}_{1}, \mathrm{C}_{3}, \mathrm{C}_{5}, \mathrm{C}_{6},\right. \\
\left.\mathrm{C}_{7}\right\} \\
(71 \%)\end{array}$ & $\begin{array}{c}\left\{\mathrm{C}_{1}, \mathrm{C}_{3}, \mathrm{C}_{5}, \mathrm{C}_{6}\right\} \\
(57 \%)\end{array}$ & & $\begin{array}{c}\left\{\mathrm{C}_{1}, \mathrm{C}_{2}, \mathrm{C}_{3}, \mathrm{C}_{4},\right. \\
\left.\mathrm{C}_{7}\right\} \\
(71 \%)\end{array}$ \\
\hline BOOT & $\begin{array}{c}\left\{\mathrm{C}_{3}, \mathrm{C}_{5}, \mathrm{C}_{6}\right\} \\
(42.90 \%)\end{array}$ & $\begin{array}{c}\left\{\mathrm{C}_{3}, \mathrm{C}_{5}, \mathrm{C}_{6}, \mathrm{C}_{7}\right\} \\
(57 \%)\end{array}$ & $\begin{array}{c}\left\{\mathrm{C}_{3}, \mathrm{C}_{5}, \mathrm{C}_{6}\right\} \\
(42.90 \%)\end{array}$ & $\begin{array}{c}\left\{\mathrm{C}_{5}, \mathrm{C}_{6}\right\} \\
(28.60 \%)\end{array}$ & \\
\hline
\end{tabular}

Legend: $\mathrm{C}_{1}-$ Speed, $\mathrm{C}_{2}-$ Cost Certainty, $\mathrm{C}_{3}-$ Time Certainty, $\mathrm{C}_{4}-$ Price Competition, $\mathrm{C}_{5}-$ Quality, $\mathrm{C}_{6}-\mathrm{Risk}$ Avoidance/Allocation (Time), $\mathrm{C}_{7}-$ Risk Avoidance/ Allocation (Cost)

NOTE: The values in bracket are the concordance indices

Table 4. Concordance threshold test for project cost of N10 million - N100 million by public clients

\begin{tabular}{|c|c|c|c|c|c|}
\hline Procurement options & $\begin{array}{c}\text { Lump sum } \\
\text { contract }\end{array}$ & Design-Build & $\begin{array}{c}\text { Management } \\
\text { contracting }\end{array}$ & Direct labour & BOOT \\
\hline Lump sum contract & & 1 & 1 & 1 & 1 \\
\hline Design-Build & 0 & & 0 & 0 & 0 \\
\hline $\begin{array}{l}\text { Management } \\
\text { contracting }\end{array}$ & 0 & 0 & & 0 & 1 \\
\hline Direct labour & 0 & 1 & 1 & & 1 \\
\hline BOOT & 0 & 1 & 0 & 0 & \\
\hline
\end{tabular}

Table 5. Multicriteria matrix for projects costing N101 million (Naira) - N500 million (Naira) by public clients

\begin{tabular}{lcccccccc}
\hline \multicolumn{1}{c}{ Procurement options } & $\mathrm{C}_{1}$ & $\mathrm{C}_{2}$ & $\mathrm{C}_{3}$ & $\mathrm{C}_{4}$ & $\mathrm{C}_{5}$ & $\mathrm{C}_{6}$ & $\mathrm{C}_{7}$ & Average \\
\hline Lump sum contract & 9.1 & 7.9 & 7.6 & 8 & 8.4 & 8.4 & 8.3 & 8.24 \\
Design-Build & 7.6 & 8.4 & 8 & 7.8 & 8.8 & 8.2 & 7.6 & 8.06 \\
Management contracting & 7.8 & 8.7 & 8.5 & 8.3 & 9.2 & 8.8 & 8.5 & 8.54 \\
Direct labour & 8.1 & 7.8 & 8.6 & 6.1 & 8.4 & 7.7 & 6.9 & 7.66 \\
BOOT & 6.7 & 5.7 & 9 & 4.7 & 9.3 & 8.7 & 7.7 & 7.4 \\
\hline
\end{tabular}

Legend: $\mathrm{C}_{1}-$ Speed, $\mathrm{C}_{2}-$ Cost Certainty, $\mathrm{C}_{3}-$ Time Certainty, $\mathrm{C}_{4}-$ Price Competition, $\mathrm{C}_{5}-$ Quality, C6 - Risk Avoidance/Allocation (Time), $\mathrm{C}_{7}-$ Risk Avoidance/Allocation (Cost) 
Therefore we have a majority of criteria 57 percent in favour of lump sum contract with respect to management contracting. Iterating the same procedure for other pairs of procurement method alternatives the values in Tables 3, 6, and 9 were obtained for cost categories of N10 million (Naira) - N100 million (Naira), N101 million (Naira) N500 million (Naira) and above N500 million (Naira) respectively.

Concordance index value varies between 0 and 1 . It is equal to 1 only if there is unanimity or a majority of criteria that are 100 percent in favour of PMi with respect to $\mathrm{PMj}$. In order to decide on the superiority of one procurement method alternative with respect to another, according to Laise (2004) a decision maker should set a concordance threshold, $\mathrm{C}^{*}$. Generally, it is chosen to be a majority greater than 50 percent (simple majority) i.e. $\mathrm{C}^{*}$ $>0.5$ (50 percent) Laise, 2004). A concordance threshold $\mathrm{C}^{*}$ test is performed as follows:

$\mathrm{Tc}(\mathrm{PMi}, \mathrm{PMj})=\left\{\begin{array}{l}1 \text { if } \mathrm{CI}(\mathrm{PMi}, \mathrm{PMj})>\mathrm{C}^{*} \\ 0 \text { if otherwise }]\end{array}\right\}$

Concordance threshold test value of 1 means PMi is better than PMj while a value of 0 means PMi is not better than PMj. Tables 4, 7 and 10 are the concordance threshold tests for project cost categories of N10 million (Naira) - N100 million (Naira), N101 million (Naira) N500 million (Naira) and above N500 million (Naira) respectively.

\section{Results and Discussion}

For project cost of N10 million (Naira) - N100 million (Naira) the lump sum contract was the "best-in-rank" by the ordered set of performance as in Fig. 1 using the mean performance in Table 2. Management contracting was second best followed by direct labour, design-Build and BOOT. The ordered set of performance in Fig. 1 implies that, the lump sum contract performs better when compared against the selection criteria than all other procurement method. However, in comparing the ordering using outranking - satisfying methodology as in Fig. 2 derived from Table 4, lump sum contract was still the "best-in-rank". By the mean performance analysis, (using arithmetic mean) of Ojo (2009), design-build was rated better on the selection criteria than BOOT, but by the outranking satisfying methodology, BOOT system performed better on four criteria out of seven than designbuild and so ranked better than design-build.

Also management contracting was rated as second best against the selection criteria and direct labour system as third, the BOOT system rated last using the averaging method as in Fig. 1. However, these positions changed significantly using the outranking-satisfying method because the direct labour system is now rated second and management contracting and BOOT system were both rated third.

The multi-criteria matrix for project cost of N101 million (Naira) - N500 million (Naira) in Table 5 was used to order the performance of the procurement method alternatives as in Fig. 3.

It indicates that management contracting was the "best-in-rank" followed by lump sum contract, designbuild, direct labour and BOOT. The implication is that using the averaging method as in Ojo (2009) in determining the performance of procurement methods against selection criteria, the management contracting would be associated with the highest performance than all other procurement methods while the BOOT system would be associated with the least performance. The outranking satisfying methodology in Table 7 and Fig. 4 show that management contracting was still the "best-inrank" followed by lump sum contract as in the mean performance result.

However, BOOT system, the "least-in-rank" by the mean performance analysis was third while the direct labour, now the "least-in-rank". The implication of the result in Fig. 4 is that for the outranking-satisfying method, the BOOT system performs better on the selection criteria than the direct labour.

The ordered set of performance in Fig. 5 arising from the multi-criteria matrix for project cost of above N500 million (Naira) (Table 8) shows that, management contracting was the "best-in-rank".

Lump sum contract was second best while the BOOT system was the "least-in-rank". This then means, the management contracting performs better than all other procurement method against selection criteria while the BOOT system is associated with the least performance. However, the order changed using the concordance threshold test of Table 10 in ordering the performance of the procurement methods. By the outranking satisfying methodology, management contracting was still the "bestin-rank" and lump sum contract as second best but designbuild, direct labour and BOOT system were not better than each other (see Fig. 6). The outranking - satisfying methodology result implies that, design - build, direct labour and BOOT system perform equally on all selection criteria.

The results derived from the analyses particularly the rank-order of the averaging and outranking-satisfying methods were discussed with some senior managers that were part of those interviewed. Sixty-five per cent $(65 \%)$ agreed more with the rank-order derived from the outranking methodology than that of the averaging method.

\section{Conclusions}

A trend emerged that both methods (the averaging method and the outranking satisfying methodology) of analysis produced the same procurement method as the 'best-inrank' for all cost categories. Also both methods produced the same procurement methods as second best except for the cost category of N10 million (Naira) - N100 million (Naira). There was however significant differences between the two methods of analysis in all other positions for all cost categories.

A close examination and further analysis of the results derived from the use of arithmetic mean on the rating of respondents of the procurement options on selection criteria, reveals that it outcome can be misleading. The rank-order derived from the use of averaging method (Ojo, 2009) clearly revealed that a difference exist between two procurement methods as a result of 0.01 difference (see Table 2, management contracting and direct labour system performances and the rank-order in Fig. 1). Whereas, for the outranking - satisfying analysis, a "wide" difference exist between the two procurement methods in favour of direct labour system (See Table 4 and Fig. 2). Hence the use of the averaging method can lead to inappropriate 
association of procurement routes with differing utility coefficients as revealed by the outranking - satisfying method. So, when it is used in the weighted sum model (which is additive in nature) can lead to choosing inappropriate procurement method. It is therefore suggested that, the outranking-satisfying methodology which involves successive pair wise comparisons be used to fix the utility coefficients rather than the mean (average) performance.

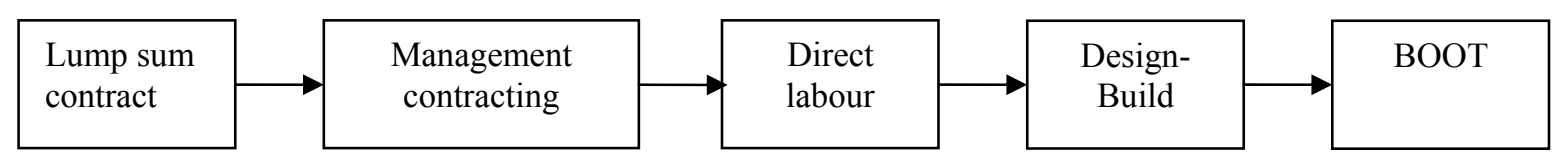

Fig. 1. Ordered set of performance of procurement methods by public clients

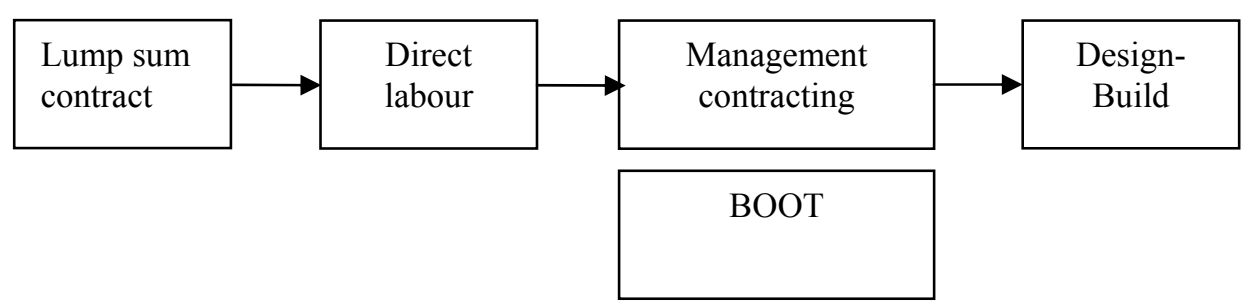

Fig. 2. Outranking relations of procurement method alternatives by public clients

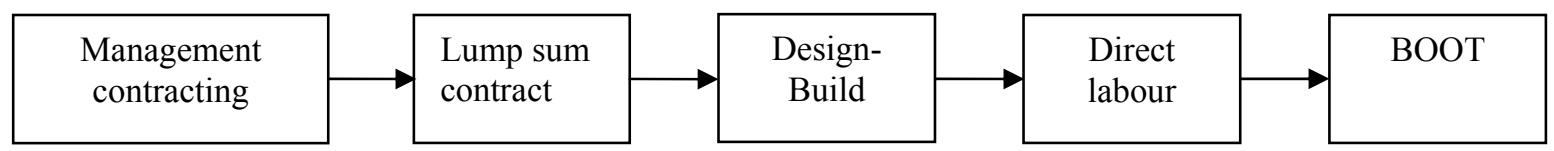

Fig. 3. Ordered set of performance of procurement methods by public clients

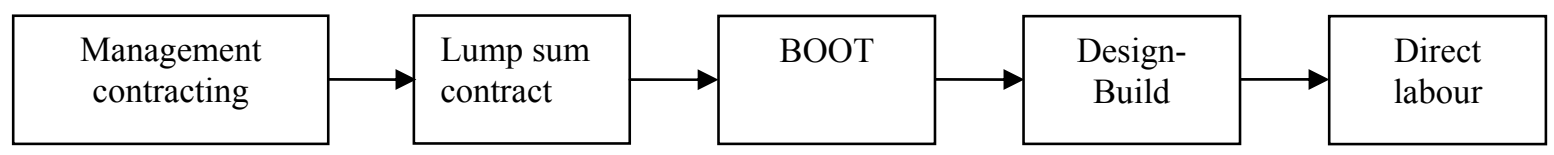

Fig. 4. Outranking relations of procurement method alternatives by public clients

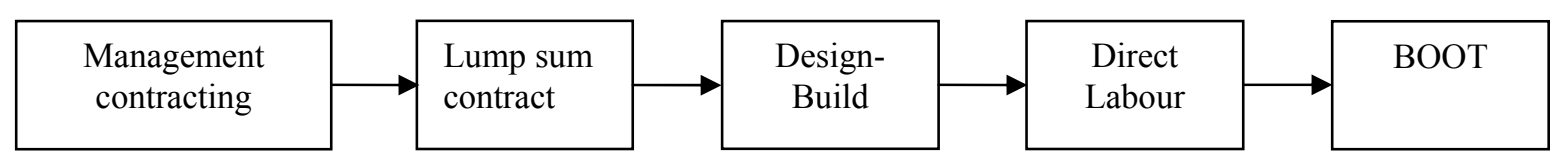

Fig. 5. Ordered set of performance of procurement methods by public clients

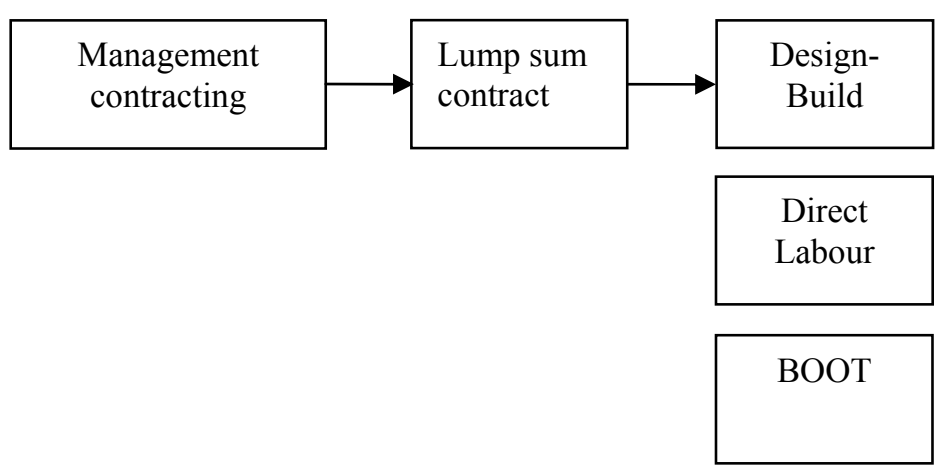

Fig. 6. Outranking relations of procurement method alternatives by public clients 
Table 6. Matrix concordance subsystem (Jc) by public clients

\begin{tabular}{|c|c|c|c|c|c|}
\hline Procurement options & $\begin{array}{c}\text { Lump sum } \\
\text { contract }\end{array}$ & Design- Build & $\begin{array}{c}\text { Management } \\
\text { contracting }\end{array}$ & Direct labour & BOOT \\
\hline Lump sum contract & & $\begin{array}{c}\left\{\mathrm{C}_{1}, \mathrm{C}_{4}, \mathrm{C}_{6}, \mathrm{C}_{7}\right\} \\
(57 \%)\end{array}$ & $\begin{array}{c}\left\{\mathrm{C}_{1}\right\} \\
(14.3 \%)\end{array}$ & $\begin{array}{c}\left\{\mathrm{C}_{1}, \mathrm{C}_{2}, \mathrm{C}_{4}, \mathrm{C}_{6},\right. \\
\left.\mathrm{C}_{7}\right\} \\
(71 \%)\end{array}$ & $\begin{array}{c}\left\{\mathrm{C}_{1}, \mathrm{C}_{2}, \mathrm{C}_{4}, \mathrm{C}_{7}\right\} \\
(57 \%)\end{array}$ \\
\hline Design-Build & $\begin{array}{c}\left\{\mathrm{C}_{2}, \mathrm{C}_{3}, \mathrm{C}_{5}\right\} \\
\quad(42.9 \%)\end{array}$ & & - & $\begin{array}{c}\left\{\mathrm{C}_{2}, \mathrm{C}_{4}, \mathrm{C}_{5}, \mathrm{C}_{6},\right. \\
\left.\mathrm{C}_{7}\right\} \\
(71 \%)\end{array}$ & $\begin{array}{c}\left\{\mathrm{C}_{1}, \mathrm{C}_{2}, \mathrm{C}_{4}\right\} \\
(42.9 \%)\end{array}$ \\
\hline $\begin{array}{l}\text { Management } \\
\text { contracting }\end{array}$ & $\begin{array}{c}\left\{\mathrm{C}_{2}, \mathrm{C}_{3}, \mathrm{C}_{4}, \mathrm{C}_{5},\right. \\
\left.\mathrm{C}_{6}, \mathrm{C}_{7}\right\} \\
(85.7 \%)\end{array}$ & $\begin{array}{c}\left\{\mathrm{C}_{1}, \mathrm{C}_{2}, \mathrm{C}_{3}, \mathrm{C}_{4}\right. \\
\left.\mathrm{C}_{5}, \mathrm{C}_{6}, \mathrm{C}_{7}\right\} \\
(100 \%)\end{array}$ & & $\begin{array}{c}\left\{\mathrm{C}_{2}, \mathrm{C}_{4}, \mathrm{C}_{5}, \mathrm{C}_{6}\right. \\
\left.\mathrm{C}_{7}\right\} \\
(71 \%)\end{array}$ & $\begin{array}{c}\left\{\mathrm{C}_{1}, \mathrm{C}_{2}, \mathrm{C}_{4}, \mathrm{C}_{6},\right. \\
\left.\mathrm{C}_{7}\right\} \\
(71 \%)\end{array}$ \\
\hline Direct labour & $\begin{array}{c}\left\{\mathrm{C}_{3}\right\} \\
(14.3 \%)\end{array}$ & $\begin{array}{c}\left\{\mathrm{C}_{1}, \mathrm{C}_{3}\right\} \\
(28.60 \%)\end{array}$ & $\begin{array}{c}\left\{C_{1}, C_{3}\right\} \\
(28.60 \%)\end{array}$ & & $\begin{array}{c}\left\{\mathrm{C}_{1}, \mathrm{C}_{2}, \mathrm{C}_{4}\right\} \\
(42.9 \%)\end{array}$ \\
\hline BOOT & $\begin{array}{c}\left\{\mathrm{C}_{3}, \mathrm{C}_{5}, \mathrm{C}_{6}\right\} \\
\quad(42.9 \%)\end{array}$ & $\begin{array}{c}\left\{\mathrm{C}_{3}, \mathrm{C}_{5}, \mathrm{C}_{6}, \mathrm{C}_{7}\right\} \\
(57 \%)\end{array}$ & $\begin{array}{c}\left\{\mathrm{C}_{3}, \mathrm{C}_{5}, \mathrm{C}_{6}\right\} \\
(42.9 \%)\end{array}$ & $\begin{array}{c}\left\{\mathrm{C}_{3}, \mathrm{C}_{5}, \mathrm{C}_{6}, \mathrm{C}_{7}\right\} \\
(57 \%)\end{array}$ & \\
\hline
\end{tabular}

Legend: $\mathrm{C}_{1}-$ Speed, $\mathrm{C}_{2}-$ Cost Certainty, $\mathrm{C}_{3}-$ Time Certainty, $\mathrm{C}_{4}-$ Price Competition, $\mathrm{C}_{5}-$ Quality, $\mathrm{C}_{6}-$ Risk Avoidance/Allocation (Time), $\mathrm{C}_{7}-$ Risk Avoidance/Allocation (Cost)

NOTE: The values in bracket are the concordance indices

Table 7. Concordance threshold test for project cost of N101 million - N500 million by public clients

\begin{tabular}{lccccc}
\hline \multicolumn{1}{c}{ Procurement options } & $\begin{array}{c}\text { Lump sum } \\
\text { contract }\end{array}$ & Design- Build & Management contracting & Direct labour & BOOT \\
\hline Lump sum contract & & 1 & 0 & 1 & 1 \\
Design-Build & 0 & 1 & 0 & 1 & 0 \\
Management contracting & 1 & 0 & 0 & 1 & 1 \\
Direct labour & 0 & 1 & 0 & 1 & 0 \\
BOOT & 0 & 1 & & \\
\hline
\end{tabular}


Table 8. Multicriteria matrix for Projects costing N500 million (Naira) above by public clients

\begin{tabular}{lcccccccc}
\hline \multicolumn{1}{c}{ Procurement options } & $\mathrm{C}_{1}$ & $\mathrm{C}_{2}$ & $\mathrm{C}_{3}$ & $\mathrm{C}_{4}$ & $\mathrm{C}_{5}$ & $\mathrm{C}_{6}$ & $\mathrm{C}_{7}$ & Average \\
\hline Lump sum contract & 9.2 & 8.8 & 8.2 & 8.2 & 9 & 7.7 & 8.7 & 8.54 \\
Design-Build & 8.8 & 8.6 & 8.2 & 8 & 9 & 8.4 & 7.8 & 8.4 \\
Management contracting & 8 & 8.7 & 8.8 & 8.5 & 9.5 & 8.8 & 8.8 & 8.73 \\
Direct labour & 8.5 & 7.7 & 9.2 & 5.8 & 8.8 & 7.7 & 7.5 & 7.89 \\
BOOT & 6.7 & 5.3 & 9 & 4.7 & 9.3 & 8.7 & 8 & 7.39 \\
\hline
\end{tabular}

Legend: $\mathrm{C}_{1}-$ Speed, $\mathrm{C}_{2}-$ Cost Certainty, $\mathrm{C}_{3}-$ Time Certainty, $\mathrm{C}_{4}-$ Price Competition, $\mathrm{C}_{5}-$ Quality, $\mathrm{C}_{6}-\mathrm{Risk}$ Avoidance/Allocation (Time), $\mathrm{C}_{7}-$ Risk Avoidance/ Allocation (Cost)

Table 9. Matrix concordance subsystem $\left(\mathrm{J}^{\mathrm{c}}\right)$ by public clients

\begin{tabular}{|c|c|c|c|c|c|}
\hline Procurement options & $\begin{array}{c}\text { Lump sum } \\
\text { contract }\end{array}$ & Design- Build & $\begin{array}{c}\text { Management } \\
\text { contracting }\end{array}$ & Direct labour & BOOT \\
\hline Lump sum contract & & $\begin{array}{c}\left\{\mathrm{C}_{1}, \mathrm{C}_{2}, \mathrm{C}_{4}, \mathrm{C}_{7}\right\} \\
(57 \%)\end{array}$ & $\begin{array}{l}\left\{\mathrm{C}_{1}, \mathrm{C}_{2}\right\} \\
(28.6 \%)\end{array}$ & $\begin{array}{c}\left\{\mathrm{C}_{1}, \mathrm{C}_{2}, \mathrm{C}_{4}, \mathrm{C}_{5}\right. \\
\left.\mathrm{C}_{7}\right\} \\
(71 \%)\end{array}$ & $\begin{array}{c}\left\{\mathrm{C}_{1}, \mathrm{C}_{2}, \mathrm{C}_{4}, \mathrm{C}_{7}\right\} \\
(57 \%)\end{array}$ \\
\hline Design-Build & $\begin{array}{c}\left\{\mathrm{C}_{6}\right\} \\
(14.3 \%)\end{array}$ & & $\begin{array}{c}\left\{\mathrm{C}_{1}\right\} \\
(14.3 \%)\end{array}$ & $\begin{array}{c}\left\{\mathrm{C}_{1}, \mathrm{C}_{2}, \mathrm{C}_{4}, \mathrm{C}_{6},\right. \\
\left.\mathrm{C}_{7}\right\} \\
(71 \%)\end{array}$ & $\begin{array}{c}\left\{\mathrm{C}_{1}, \mathrm{C}_{2}, \mathrm{C}_{4}\right\} \\
(42.9 \%)\end{array}$ \\
\hline $\begin{array}{l}\text { Management } \\
\text { contracting }\end{array}$ & $\begin{array}{c}\left\{\mathrm{C}_{2}, \mathrm{C}_{3}, \mathrm{C}_{4}, \mathrm{C}_{5},\right. \\
\left.\mathrm{C}_{6}, \mathrm{C}_{7}\right\} \\
(71 \%)\end{array}$ & $\begin{array}{c}\left\{\mathrm{C}_{2}, \mathrm{C}_{3}, \mathrm{C}_{4}, \mathrm{C}_{5},\right. \\
\left.\mathrm{C}_{6}, \mathrm{C}_{7}\right\} \\
(85.7 \%)\end{array}$ & & $\begin{array}{c}\left\{\mathrm{C}_{2}, \mathrm{C}_{4}, \mathrm{C}_{5}, \mathrm{C}_{6},\right. \\
\left.\mathrm{C}_{7}\right\} \\
(71 \%)\end{array}$ & $\begin{array}{c}\left\{\mathrm{C}_{1}, \mathrm{C}_{2}, \mathrm{C}_{4}, \mathrm{C}_{5},\right. \\
\left.\mathrm{C}_{6}, \mathrm{C}_{7}\right\} \\
(85.7 \%)\end{array}$ \\
\hline Direct labour & $\begin{array}{c}\left\{\mathrm{C}_{3}\right\} \\
(14.3 \%)\end{array}$ & $\begin{array}{c}\left\{\mathrm{C}_{3}\right\} \\
(14.30 \%)\end{array}$ & $\begin{array}{l}\left\{C_{1}, C_{3}\right\} \\
(28.6 \%)\end{array}$ & & $\begin{array}{c}\left\{\mathrm{C}_{1}, \mathrm{C}_{2}, \mathrm{C}_{3}, \mathrm{C}_{4}\right\} \\
(57 \%)\end{array}$ \\
\hline BOOT & $\begin{array}{c}\left\{\mathrm{C}_{3}, \mathrm{C}_{5}, \mathrm{C}_{6}\right\} \\
(42.9 \%)\end{array}$ & $\begin{array}{c}\left\{\mathrm{C}_{3}, \mathrm{C}_{5}, \mathrm{C}_{6}, \mathrm{C}_{7}\right\} \\
(57 \%)\end{array}$ & $\begin{array}{c}\left\{\mathrm{C}_{3}\right\} \\
(14.3 \%)\end{array}$ & $\begin{array}{c}\left\{\mathrm{C}_{5}, \mathrm{C}_{6}, \mathrm{C}_{7}\right\} \\
(42.9 \%)\end{array}$ & \\
\hline
\end{tabular}

Legend: $\mathrm{C}_{1}-$ Speed, $\mathrm{C}_{2}-$ Cost Certainty, $\mathrm{C}_{3}-$ Time Certainty, $\mathrm{C}_{4}-$ Price Competition, $\mathrm{C}_{5}-$ Quality, $\mathrm{C}_{6}-$ Risk Avoidance/Allocation (Time), $\mathrm{C}_{7}-$ Risk Avoidance/Allocation (Cost)

NOTE: The values in bracket are the concordance indices. 
Table 10. Concordance threshold test for project cost of N500 million above by public clients

\begin{tabular}{|c|c|c|c|c|c|}
\hline Procurement options & $\begin{array}{c}\text { Lump sum } \\
\text { contract }\end{array}$ & Design -Build & Management contracting & Direct labour & BOOT \\
\hline Lump sum contract & & 1 & 0 & 1 & 1 \\
\hline Design-Build & 0 & & 0 & 1 & 0 \\
\hline Management contracting & 1 & 1 & & 1 & 1 \\
\hline Direct labour & 0 & 0 & 0 & & 1 \\
\hline BOOT & 0 & 1 & 0 & 0 & \\
\hline
\end{tabular}

\section{References}

Ambrose, M. D. and Tucker, S. N. (2000). Procurement system evaluation for the construction industry. Journal of Construction Procurement, 6(2), 121-134.

Bennett, J. and Grice, T. (1990). Procurement Systems for Building. In: Quantity Surveying Techniques. New Directions. P. S. Brandon (ed). Blackwell Scientific Publications, Oxford. 243-261.

Bilge, G. C. and Sharmin, A. (2012). A Conceptualization for Using Analytical Hierarchy Process in Green Building Market Research. Proceedings of $48^{\text {th }}$ Associated Schools of Construction (ASC) Annual International Conference, Birmingham City University, Birmingham, UK.

Chan, A. P. C. (1995). Towards an expert system on project procurement. Journal of Construction Procurement, 1(2), 124-149.

Chan, A. P. C., Yung E. H. K., Lam, P. T. I., Tam, C. M., and Cheung, S. O. (2001). Application of delphi method in selection of procurement systems for construction projects. Construction Management and Economics, 19, 699-718.

Chang, C and Ive, G. (2002). Rethinking the multiattribute utility approach based procurement route selection technique. Construction Management and Economics, 20, 275-284.

Cheung, S., Lam, T., Leung, M., and Wan, Y. (2001). An analytical hierarchical process based procurement. Construction Management and Economics, 19, 427437.

Dada, M. O. (2012). Analysis of conflict centers in projects procured with traditional and integrated methods in Nigeria. Journal of Engineering, Project and Production Management, 2(2), 66-77.

Drew, S. A. (1997). From knowledge to action: the impact of benchmarking on organizational performance. Long Range Planning, 30(3), 427-441.

Emerson, H. (1962). Report Ministry of Works: Survey of Problems Before the Construction Industries. HMSO, London.

Fellows, R. F. and Langford, D. A. (1980). Decision theory and tendering. In Building Technology and Management, Chartered Institute of Building, Ascot, 36-39.

Goh, S and Richards, G. (1997). Benchmarking the learning capability of organizations. European Management Journal, 15(5), 575-583.
Ireland, V. (1985). The role of managerial actions in cost, time and quality performance of high commercial building projects. Construction Management and Economics, 3(1), 59-87.

Jiukun, D., Goodrum, P. M., and Maloney, W. F. (2007). Analysis of craft workers' and foremen's perception of the factors affecting construction labour productivity. Construction Management and Economics, 25(11), 1139-1152.

Kumaraswamy, M. M. and Dissanayaka, S. M. (1998). Linking procurement systems to project priorities. Building Research and Information, 20(4), 223-238.

Kumaraswamy, M. M. and Dissanayaka, S. M. (2001). Developing a decision support system for building project procurement. Building and Environment, 36 (3), 337-349.

Laise, D. (2004). Benchmarking and learning organizations, rankings methods to identify "best in class." Benchmarking: An International Journal, 11(6), 621-630.

Latham, M. (1994). Report: Department of the Environment: Constructing the Team, HMSO, London.

Love, P. E. D., Skirtmore, M., and Earl, G. (1998). Selecting a suitable procurement method for a building project. Construction Management and Economics, 16, 221 - 233.

Mendenhall, W., Ott, L., and Scheafter, R. L (1971). Elementary Survey Sampling. Wadsworth Publishing Company Inc. Belmont, California, 46-49

Muriro, A. and Wood, G. (2010). A Comparative Analysis of Procurement Methods Use on Competitively Tendered Office Projects in the UK. The Construction, Building and Real Estate Research Conference of the Royal Institution of Chartered Surveyors. Held at Deuiphine Université, Paris.

Ng, T. S., Luu, D. C., Chen, S. E., and Lam K. C. (2002). Fuzzy membership functions of procurement selection criteria. Construction Management and Economics, 20, 285-290

Ogunsanmi, O. E., Salako, O. A., and Ajayi, O. M. (2011). Risk identification model for design and build projects. Journal of Engineering, Project and Production Management, 1 (1), 46-60.

Ojo, S. O. (2009). Benchmarking the performance of construction procurement methods against selection criteria in Nigeria. Civil Engineering Dimensions, 2(2), 106-112 
Ojo, S. O. and Aina, O. O. (2010). Developing a decision support system for the selection of appropriate procurement method for a building project in Nigeria. Global Journal of Researches in Engineering, 10(2), 18-30.

Ren, Z., Kwaw, P., and Yang, F. (2012). Ghana's public procurement reform and the continuous use of the traditional procurement system: the way forward. Built Environment Project and Asset Management, 2(1), 56-69.

Sharif, A. M. (2002). Benchmarking performance management systems. Benchmarking: An International Journal, 9, 66-85.

Skitmore, M and Marsden, D. E. (1988). Which procurement system? Towards a universal procurement selection technique. Construction Management and Economics, 6(1), 71-89.

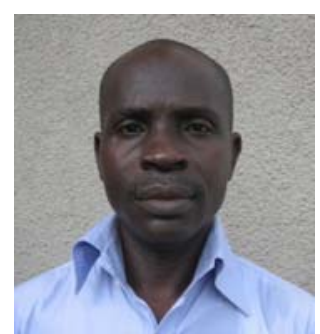

Dr. Stephen O. Ojo is a Senior Lecturer in the Department of Building at the Obafemi Awolowo University, Ile-Ife, Nigeria. He obtained his Bachelor of Science degree in Civil Engineering in 1989 from University of Ibadan, Ibadan, Nigeria while his MSc and Ph.D. degrees in Construction Management were obtained from Obafemi Awolowo University, Ile-Ife, Nigeria in 1999 and 2008 repectively. He had worked in the construction industry in the area of design and production management. $\mathrm{He}$ is a member of the Nigerian Society of Engineers, Member, American Society of Civil Engineers, Member, Nigerian Institute of Building and Incorporate Member, Chartered Institute of Building. His research is in the area of procurement methods and labour productivity in concreting.

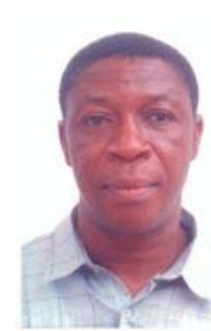

Prof. Imeh J. Ikpo is a Professor in the Department of Building at the Obafemi Awolowo University, IleIfe, Nigeria. He obtained a Diploma in Estate Management in 1975 from Calabar Polytechnic Calabar, Nigeria. $\mathrm{He}$ obtained a Bachelor of Science degree in Estate Management in 1979, M.Sc. in Maintenance Management in 1983 and Ph.D. in Building Maintenance in 1990 all from Obafemi Awolowo University, Ile-Ife, Nigeria. He is a member of Nigerian Institute of Building and registered by the Council of Registered Builders of Nigeria. His research focus is in the area of maintenance and reliability studies. 